\title{
深層水活用型海洋肥沃化装置の動摇性能に関する 実験的研究
}

\author{
正員 小 林 英 一* \\ 正員 和 田 洋二郎* \\ 正員 宮 部 宏 彰***
}

\author{
大 江 清 登** \\ 正員 福 嶋 祐 二* \\ 正員大 内
}

An Experimental Study on Dynamic Characteristics of Deep Ocean Water Upwelling

Floating Structure for Eutrophication

\author{
by \\ Eiichi Kobayashi, Member \\ Yojiro Wada, Member \\ Kiyoto Oe \\ Hiroaki Miyabe, Member \\ Yuhji Fukushima, Member \\ Kazuyuki Ouchi, Member
}

\begin{abstract}
Summary
The Marino Forum 21 started an R\&D project in fiscal 2000 with grants from the Japanese Ministry of Agriculture, Forestry, and Fishery to develop the equipment for the eutrophication of the sea by upwelling deep ocean water, sending into euphotic zone and increasing phytoplankton.

First, some concepts of moored floating structure with a riser pipe for deep ocean water upwelling at the water depth of $500 \mathrm{~m}$ were investigated and evaluated by computer runs. Second, based on the investigation, basic design of the structure was undertaken. Next, scaled model tests were carried out in an experimental tank at several wave conditions in order to evaluate dynamic response of motion of the structure, mooring force and riser pipe stress. Finally, based on this experiment, possibility of the structure and validity of the computation were verified.
\end{abstract}

\section{1. 粕 言}

海洋深層水は水深 $200 \mathrm{~m}$ 程度以深の海水で, この水深域 では光合成が行われないため無機栄養塩が豊富にある という特徵を有している。この深層水は海洋深部を緩や かに流れているが，自然に表層に湧き上がり有光層に送 り込まれる湧昇域では好漁場になりやすいといわれて いる。

(社)マリノフォーラム 21 ではこの深層水を汲み上げ 有光層に放出して植物プランクトンを増加させること により，海洋を肥沃化させ漁場創成を狙う水産庁プロジ

* 三菱重工業（株）長崎研究所

**三菱重工業（株）本社船舶技術部

*** 石川島播磨重工業（株）船舶海洋技術統括部

****（株）大内海洋コンサルタント

原稿受理 平成 13 年: 7 月 10 日

秋季講演会に扔いて講演 平成 13 年 11 月 15,16 日
エクト「深層水活用型漁場造成技術開発」を平成 12 年 度から 5 ケ年計画でスタートさせた。本プロジェクトで は深層水を汲み上げ有光層に放出する装置の設計・製作 を行い，実海域に設置しその効果を把握することが計画 されている。

本報告ではまずこのプロジェクトの一環として実施 した, 水深 $500 \mathrm{~m}$ 程度の海域において揚水管を垂下した 係留躯体から深層水を機械的に汲み上げる装置の基本 的なコンセプトの検討及び基本計画を示す。次にこの装 置の相似模型による水槽試験を実施し動摇性能, 係留力, 管応力などについて予測計算ツールの精度検証を行う とともに成立性の検証についての検討結果について言 及する。

\section{2. 躯体の初期設計}

海洋肥沃化装置の開発では, 技術的実現性と経済性か らのフィージビリティスタディを行い, 実現可能なシス 
テムを抽出した。装置の設置を想定した海域における気 象・海象条件の中で，その機能を十分に発揮する躯体形 式として没水型躯体が選択された。ここでは気象・海象 条件を設定し，それに適合する躯体形式の選定等，基本 設計について概説する 1)22。

\section{1 気象・海象条件}

躯体の設計にあたって, 気象・海象条件を設定するた めには海洋肥沃化装置の設置海域を想定する必要があ る。設置海域は肥沃化装置としての機能を十分に発揮で きる海域が望ましいが，これは設置する海域の地形，水 質, 深層水汲み上げ量に大きく依存する。したがって, 複数の想定された設置海域について, 設計に必要な波浪 や水深, 海流等の他に, 水温分布, 栄養塩分布について も資料調査と現地調查を実施した。

こうした調查の結果, 相模湾中央部の相模海丘の頂上, 水深約 $450 \mathrm{~m}$ 付近が設置場所の第 1 候補として選定され た。

本計画が実証実験として位置付けられることから, 耐 用年数を 10 年と定め, 躯体部分の構造と材料, ライザ 一の強度, 倸留装置の安全性等を耐用年数とあわせて評 価し，躯体構造の設計条件を Table 1 にまとめた。

特に波浪条件は, 想定海域において再現期間 20 年程 度であり，構造設計上も十分な必要限界を与えている。

\section{2 壆体形式の選定}

没水型, 半没水型, ポンツーン型の 3 種類のコンセプ トから本装置に適した躯体形式として 7 種類の構造を考 案した。さらに各々の躯体形式に対して, 基本性能, 操 作性, 運用の利便性, コストなどを評価項目とした比較 検討の結果から最適形状として没水型を採用すること とした。

この型式を採用することにより水線面積が小さくで き，また，鋼製のライザーにより重心が低くなるため， メタセンターが大きくなることなどから，波浪中で極め て優れた動摇性能が期待できる。こうした設計検討を通 じて設定された躯体の主要寸法を Table 2 に示す。

\section{3 一般配貫}

本装置は深層水を汲み上げ，表層水と混合して放流し， 密度流拡散の原理を利用して海洋温度差発電(OTEC)を 利用することを想定している。

躯体の一般配置図を Fig. 1 に示す。躯体は躯体部分と ライザーで構成され，躯体の上部から，制御室，表層水 取水管, 上部機関室, インペラ, 下部機関室, バラスト タンク，固定バラスト室のように配置され，表層水と
Table 1 Environmental conditions

\begin{tabular}{|l|c|}
\hline Significant wave height & $10 \mathrm{~m}$ \\
\hline Mean wave period & $14 \mathrm{~s}$ \\
\hline Design wind velocity & $50 \mathrm{~m} / \mathrm{s}$ \\
\hline Residual current velocity & $0.2 \mathrm{~m} / \mathrm{s}$ \\
\hline Current & $0.1 \mathrm{~m} / \mathrm{s}$ \\
\hline Wind drift & $0.5 \mathrm{~m} / \mathrm{s}$ \\
\hline Durability & $10 \mathrm{years}$ \\
\hline
\end{tabular}

Table 2 Principal particulars of the floating structure

\begin{tabular}{|l|c|}
\hline Height & About $60 \mathrm{~m}$ \\
\hline Breadth & $30 \mathrm{~m}$ \\
\hline Displacement & $5,750 \mathrm{t}$ \\
\hline Internal diameter of riser & $2.50 \mathrm{~m}$ \\
\hline Length of riser & About $400 \mathrm{~m}$ \\
\hline
\end{tabular}

深層水が適度に混ぜ合わされた混合水はインペラによ り放射状に接続される放水口から放流される。

水面貫通部は表層水を取水するため管状とし，この表 層水取水管の上には, 制御室を備え, 本装置による海洋 肥沃化効果をモニターし種々のデータを送受信するた めの機器が装備される。躯体の中心部には表層水と深層 水を引き込むインペラを配置し，これを挟んで上下に機 関室を設けた構造とした。梁層水取水のためのライザー が機関室を貫通して,インペラ部吸入口へ接続される。 また, OTEC 等の機器類は上下の機関室に配置される。

保守点検時（メンテナンス状態）にはバラスト水を排 水し, 放水口デッキ下まで浮上して通船のアクセスを容 易にする。躯体の設置工事や躯体の現地への曳航を容易

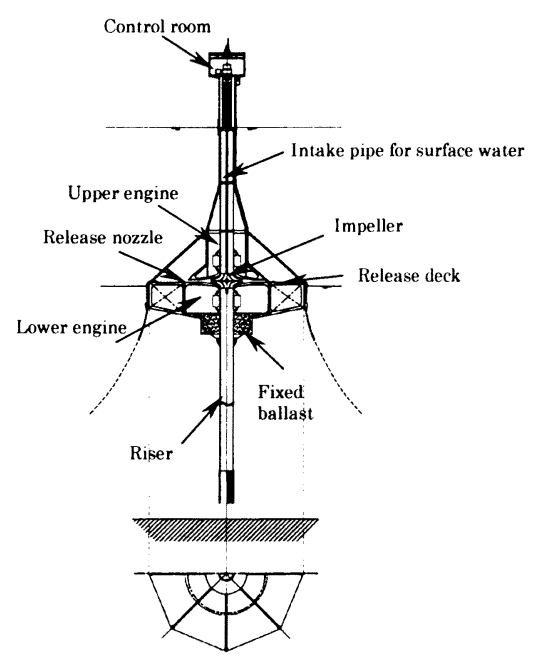

Fig.1 General arrangement of the floating structure 
にするため，躯体は固定バラストにより，単体でも直立 を保つようにした。

\section{3. 躯体の係留系に関する初期検討}

躯体システムの係留系としては種々の方式が考えら れるが，本装置の係留方式を選定するに際しては，以下 に示す条件を考慮し, 最も一般的で実績が多いカテナリ 一倸留方式を選定した。

（1）水深 $500 \mathrm{~m}$ の海域へも適用可能である

（2）係留系の製作コストが安い

（3）設置作業が比較的容易で，設置コストが安い

（4）躯体の動摇は，ある程度は許容できる

（5）設置後の保守管理が比較的容易である

本章では, カテナリ一倸留方式を対象として設計外乱 条件下での躯体システムの動摇及び係留力を理論計算 により求め, 躯体形状や係留方式の本システムへの適用 性に関する見通しを得るための初期検討を行った。

\section{1 㩽体単独時の動搯性能}

係留系を含む躯体システムの応答について検討する 前に，まず，基本となる躯体単体時（倸留系なし）の動 摇性能について検討した。条件としては実際の運用を想 定したオペレーション状態と保守・点検を行う場合のメ ンテナンス状態とした。

躯体単独時の Heave, Roll（波の進行方向を含む面内 での回転運動）の規則波中応答関数を Fig. 2, 3 に示す。 横軸は波周期, 縦軸は波振幅 $1 \mathrm{~m}$ 当たりの動摇振幅を 表している。Fig. 2 は オペレーション状態, Fig. 3 は メンテナンス状態の結果である。

ライザーの影響を把握するため， "ライザーなし", "ライザー付き”(剛体と仮定) の結果を比較している。 これらの結果により本躯体はオペレーション状態にお いて, 上下動, 横摇れともに小さく, 良好な性能を有し ていることが分かる。またライザーが受ける潮流力によ って平均的な傾斜を生じると予想されるが, Rolling に 及ぼすライザー抵抗の影響は非常に大きく, ライザーを 装備することによって応答が非常に小さく抑えられる ことが分かる。

\section{2 係留チェーンに関する検討}

係留時の躯体の応答を計算するため, Table 3 に示す 3 種類の係留チェーンを仮定した。各ケースにおけるチ エーン 1 本当たりの係留特性を Fig. 5 ～8 に示す。又各 図に示す特性の定義をFig. 4 に示す。
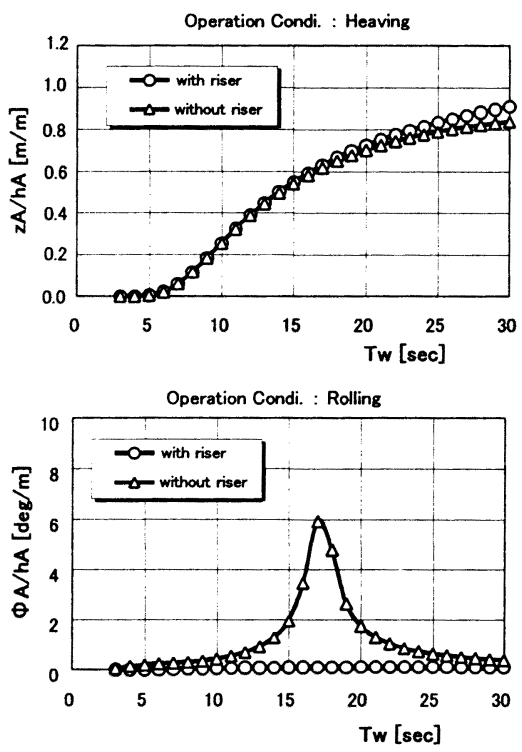

Fig.2 Response in regular waves without mooring lines ( operating draft)
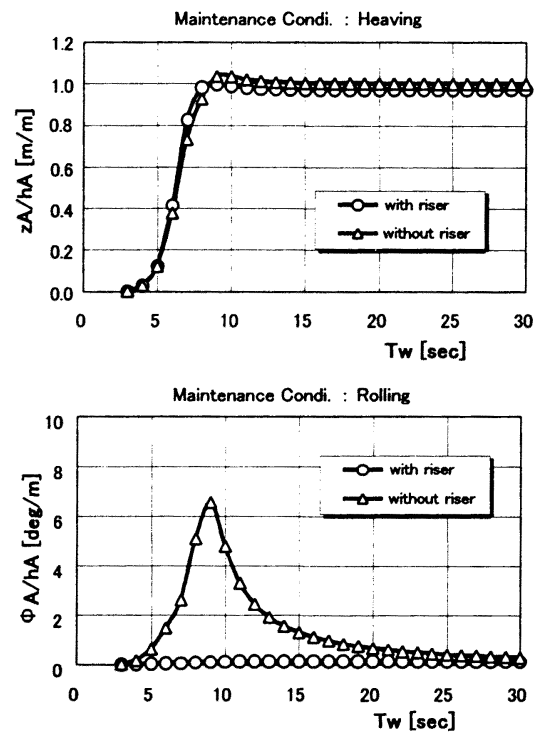

Fig.3 Response in regular waves without mooring lines( maintenance draft)

Table 3 Specification of mooring chains

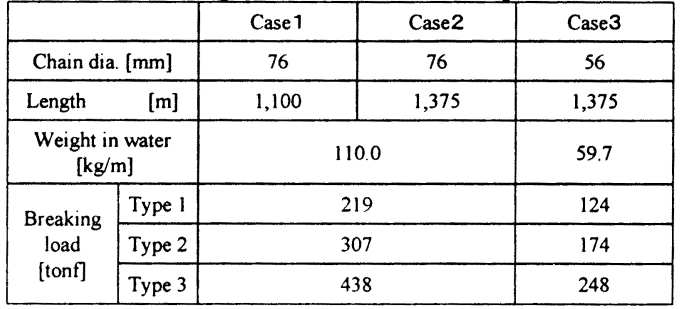




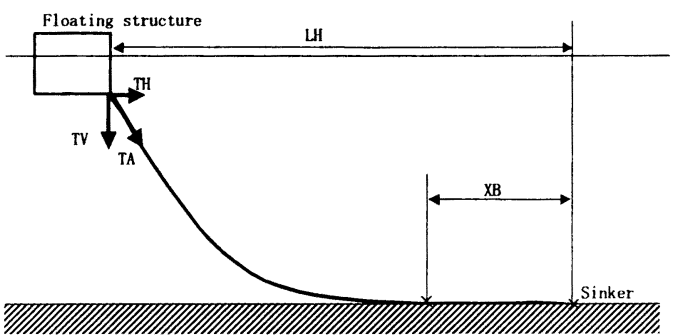

Fig.4 Definition of mooring characteristics

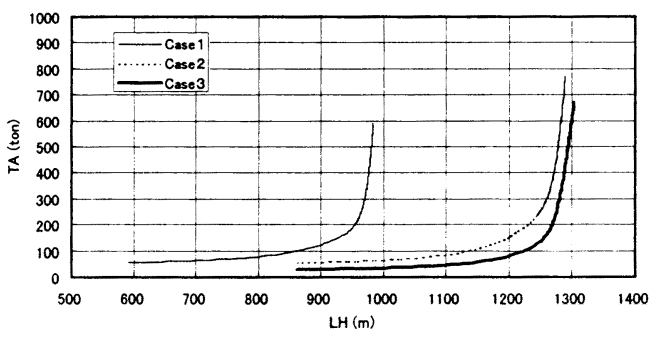

Fig.5 Mooring characteristics (tension)

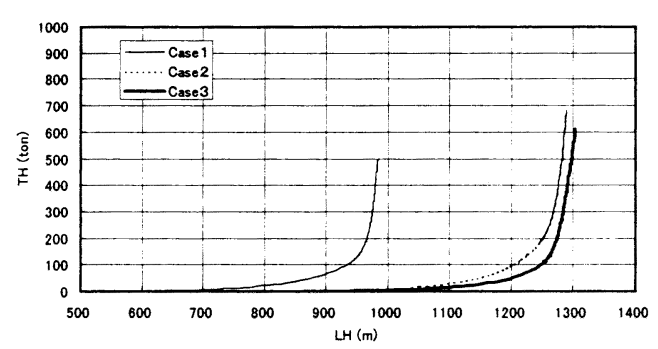

Fig.6 Mooring characteristics

( horizontal component of tension)

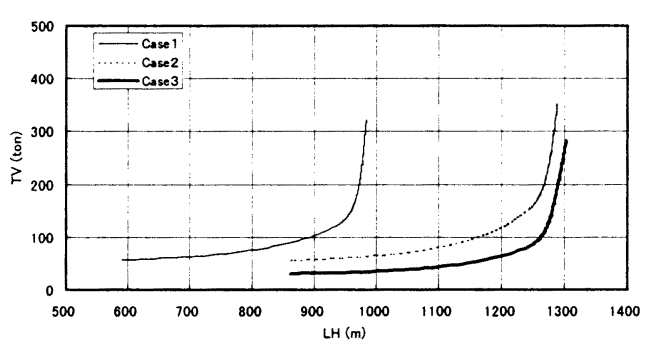

Fig.7 Mooring characteristics

(vertical component of tension)

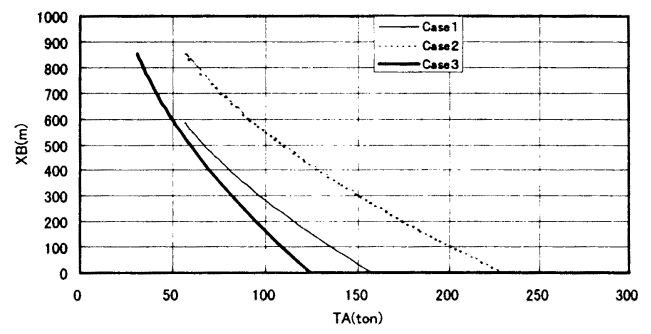

Fig.8 Mooring characteristics

( length of chain on the sea bed )

ここで，躯体システムの投影面積を約 $1,600 \mathrm{~m}^{2}$ （躯体 $400 \mathrm{~m}^{2}$, ライザー $\left.1,200 \mathrm{~m}^{2}\right)$ ，余裕を考慮して潮流速度を $2 \mathrm{kn}$ （水墚方向に一様分布）と仮定して躯体システムが 受ける潮流力を 89 ton（定常力, $C_{D}=1.0$ と仮定）とし, チェーンの平均作動点を計算した。Fig. 5〜8 より求めた 係留要目をTable 4 に示す。

いずれのケースも XB が正値となりチェーンは緊張状 態にはなくカテナリーを形成している。ケース 2 ではチ エーン長に余裕があり過ぎることや, コスト・ハンドリ ング・躯体の排水量等を考慮すると倸留系は軽い方がよ いと考えられるため, 以後の検討においてはケース $3 に$ 示す $56 \mathrm{~mm}$ 径のチェーンを選択した。

Table 4 Mooring particulars for 3 cases of chain

\begin{tabular}{|l|c|c|c|c|c|}
\hline & Chain Dia. & LH[m] & TV [ton] & TA[ton] & XB[m] \\
\hline Case1 & $76 \mathrm{~mm}$ & 920 & 115 & 150 & 30 \\
\hline Case2 & $76 \mathrm{~mm}$ & 1195 & 115 & 150 & 305 \\
\hline Case3 & $56 \mathrm{~mm}$ & 1240 & 80 & 120 & 40 \\
\hline
\end{tabular}

\section{4. 水槽試検}

波浪外乱下における躯体システムの動摇・応力・倸留 特性などの設計データを取得し, 設計に使用する理論計 算法を検証するため, 躯体・ライザ・係留から構成され る全体システムの波浪中での水槽試験を実施した。

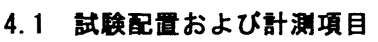

躯体運動及びライザー挙動を実験的に把握するため, ライザー管の模型を装備した躯体・ライザ管・倸留索の 縮尺比 $1 / 72.2$ の模型を使用した。ライザー模型は, 作 用する流体力，曲げ剛性を実機と合わせるためFig. 9 に 示すように縮尺比の 5 秊で曲げ剛性を合わせたアルミ 丸棒に実機と同じ直径に相当する直径の FRP 製パイプ 


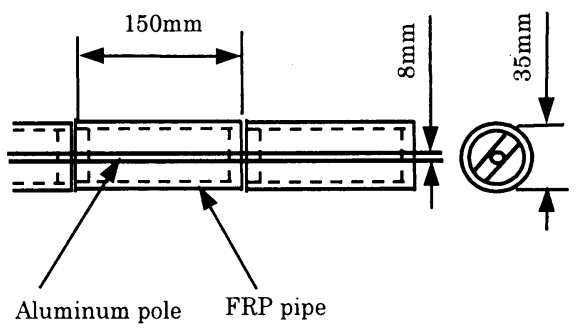

Fig.9 Construction of riser tube model used in the experiments

を、これが剛性を持たないよう一定間隔で隙間を設けて 取り付けた。また水中重量を合わせるため円筒管内に浮 力材を固定した。

試験状態を Table 5 に示す。試験は三菱重工業(株) 長 崎研究所／推進性能水槽において実施した。試験配置お よび計測項目を Fig. 10〜12 に示す。また, 躯体運動の 定義をFig. 13，各状態における波浪条件をTable 6 に示 す。

\section{(1) 躯体動摇}

光学式非接触運動計測装置を使用し, 躯体模型に取 付けたターゲット（発泡材カラーボール）を自動追 跡して計測した。

(2) 加速度

躯体上部に歪みゲージ式加速度計を取付け，上下お よび前後方向加速度を計測した。

(3) 索張力

歪ゲージ式の小型軽量張力計を躯体と係留索の間に 取付け，張力を計測した。

(4) ライザー管の曲げモーメント

躯体とライザー管の接合部およびシミュレーション 結果から予想された変位・応力の大きい個所に歪ゲ ージを貼り付けライザーに作用する応力を計測した。

（5）ライザー管の水中挙動

ライザー管の挙動を水中カメラにて撮影した。 試験では，合計で実機 1 時間相当（模型で約 $430 \mathrm{sec}$ ） になるように 3 回の計測を行った。各々の計測では 同じ波スペクトルを使用するが, 各成分波の位相 (乱 数）を変更することにより異なった出会い波となる ようにした。

Table 6 Wave conditions in the experiments

\begin{tabular}{|c|c|c|c|c|c|}
\hline Condition & \multicolumn{5}{|c|}{ Waves } \\
\hline Operation & $\begin{array}{l}\text { - Irregular waves } \\
\text { - Regular waves }\end{array}$ & $\begin{array}{l}\text { Significant wave height } \\
\text { Wave height }\end{array}$ & $\begin{array}{r}10 \mathrm{~m} \\
5 \mathrm{~m} .\end{array}$ & $\begin{array}{l}\text { Mean wave period } \\
\text { Wave period }\end{array}$ & $\begin{array}{l}14 \mathrm{sec} \\
14 \mathrm{sec}\end{array}$ \\
\hline Maintenance & - Irregular waves & Significant wave height & $1.5 \mathrm{~m}$. & Mean wave period & $6 \mathrm{sec}$ \\
\hline Light & - Irregular waves & Significant wave height & $1 \mathrm{~m}$. & Mean wave period & $\begin{array}{l}6 \mathrm{sec} \\
8 \mathrm{sec}\end{array}$ \\
\hline
\end{tabular}

Table 5 Conditions and particulars of floating structure in the experiments Scale : 72.2

\begin{tabular}{|l|rccc|}
\hline \multicolumn{1}{|c|}{ Item } & \multicolumn{2}{|c|}{ Full scale } & \multicolumn{2}{c|}{ Model scale } \\
\hline Depth of water & 460 & $\mathrm{~m}$ & 6.375 & $\mathrm{~m}$ \\
& & & & \\
Riser & & & & \\
Length & 410 & $\mathrm{~m}$ & 5.682 & $\mathrm{~m}$ \\
Diameter & 2.545 & $\mathrm{~m}$ & 0.0353 & $\mathrm{~m}$ \\
Internal diameter & 2.500 & $\mathrm{~m}$ & 0.0346 & $\mathrm{~m}$ \\
Weight in water & 1.220 & $\mathrm{ton} / \mathrm{m}$ & 0.229 & $\mathrm{~kg} / \mathrm{m}$ \\
Elastic coefficient E & $2.000 \mathrm{E}+06$ & $\mathrm{~kg} / \mathrm{cm}^{2}$ & $2.704 \mathrm{E}+04$ & $\mathrm{~kg} / \mathrm{cm}^{2}$ \\
Bending rigidity EI & $2.837 \mathrm{E}+06$ & ton $\cdot \mathrm{m}^{2}$ & $1.415 \mathrm{E}+04$ & $\mathrm{~kg} \cdot \mathrm{cm}^{2}$ \\
& & & & \\
Mooring line (60mm $\Phi$ chain) & & & & \\
Length & 900 & $\mathrm{~m}$ & 12.473 & $\mathrm{~m}$ \\
Weight in water & 68.55 & $\mathrm{~kg} / \mathrm{m}$ & 0.01284 & $\mathrm{~kg} / \mathrm{m}$ \\
Horizontal length LH & 600 & $\mathrm{~m}$ & 8.315 & $\mathrm{~m}$ \\
\hline
\end{tabular}

\begin{tabular}{|c|c|c|c|c|}
\hline \multicolumn{3}{|c|}{ Floating structure and riser (operation) } & \multirow[b]{2}{*}{15.02} & \multirow[b]{2}{*}{$\mathrm{kg}$} \\
\hline Displacement $\Delta \mathrm{a}$ & 5,784 & ton & & \\
\hline Draft $d^{*}$ & 450.0 & $\mathrm{~m}$ & 6.236 & $\mathrm{~m}$ \\
\hline Diameter & 30.0 & $\mathrm{~m}$ & 0.416 & $\mathrm{~m}$ \\
\hline GM & 18.6 & $\mathrm{~m}$ & 0.258 & $\mathrm{~m}$ \\
\hline $\mathrm{KG} *$ & 397.7 & $\mathrm{~m}$ & 5.511 & $\mathrm{~m}$ \\
\hline Initial tension $\mathrm{TA}$ & 38 & ton & 0.099 & $\mathrm{~kg}$ \\
\hline
\end{tabular}

\begin{tabular}{|l|rl|rl|}
\hline \multicolumn{2}{|l|}{ Floating structure and riser (maintenance) } & & & \\
Displacement $\Delta \mathrm{a}$ & 3,960 & ton & 10.28 & $\mathrm{~kg}$ \\
Draft d* & 419.2 & $\mathrm{~m}$ & 5.810 & $\mathrm{~m}$ \\
Diameter & 30.0 & $\mathrm{~m}$ & 0.416 & $\mathrm{~m}$ \\
$\mathrm{GM}$ & 34.4 & $\mathrm{~m}$ & 0.476 & $\mathrm{~m}$ \\
KG * & 388.7 & $\mathrm{~m}$ & 5.386 & $\mathrm{~m}$ \\
Initial tension TA & 42 & ton & 0.109 & $\mathrm{~kg}$ \\
\hline
\end{tabular}

\begin{tabular}{|c|c|c|c|c|}
\hline \multicolumn{5}{|c|}{ Floating structure (light) } \\
\hline Displacement $\Delta \mathrm{a}$ & 3,000 & ton & 7.79 & $\mathrm{~kg}$ \\
\hline Draft $d^{* *}$ & 7.7 & $\mathbf{m}$ & 0.107 & $\mathrm{~m}$ \\
\hline Diameter & 30.0 & $\mathrm{~m}$ & 0.416 & $\mathbf{m}$ \\
\hline GM & 14.3 & $\mathrm{~m}$ & 0.198 & $\mathrm{~m}$ \\
\hline $\mathrm{KG}^{* *}$ & 6.0 & $\mathrm{~m}$ & 0.083 & $\mathrm{~m}$ \\
\hline Initial tension $\mathrm{TA}$ & 42 & ton & 0.109 & $\mathrm{~kg}$ \\
\hline
\end{tabular}

* from riser bottom
** from structure bottom

Video camera for

measurement of motion Target for measurement
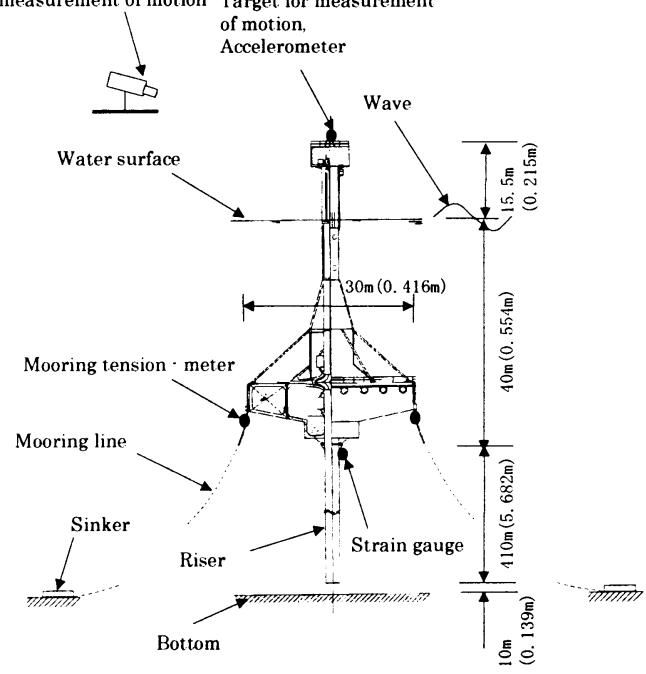

$※(\quad)$; Hodel values

Fig.10 Measured items and arrangement of apparatus 


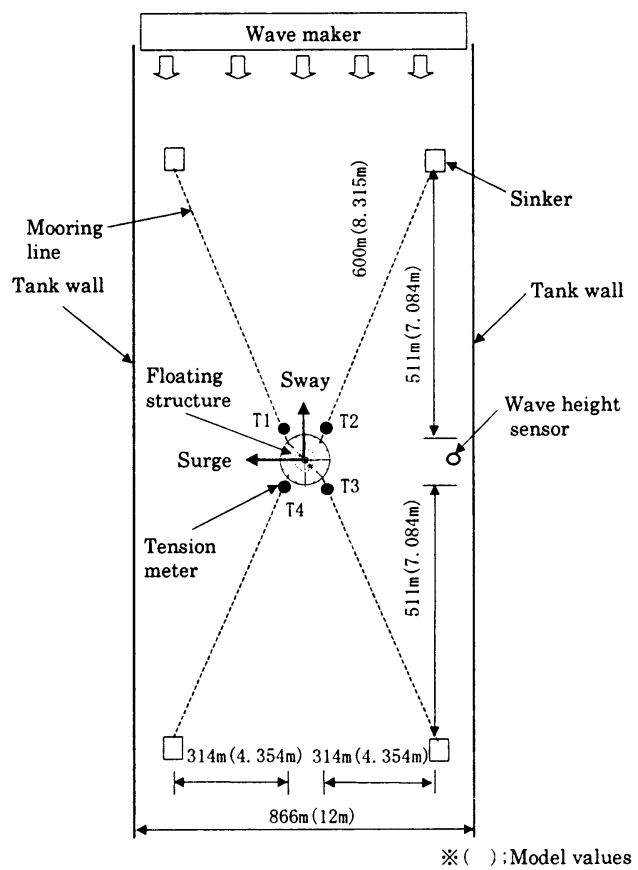

Fig.11 Arrangement of floating system in the experiments

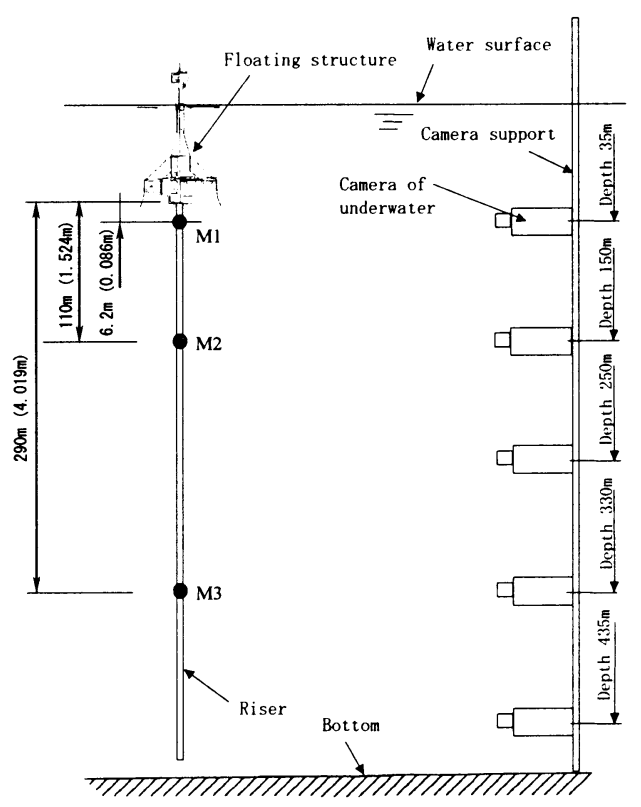

Fig.12 Arrangement of apparatus for the measurement of riser tube response

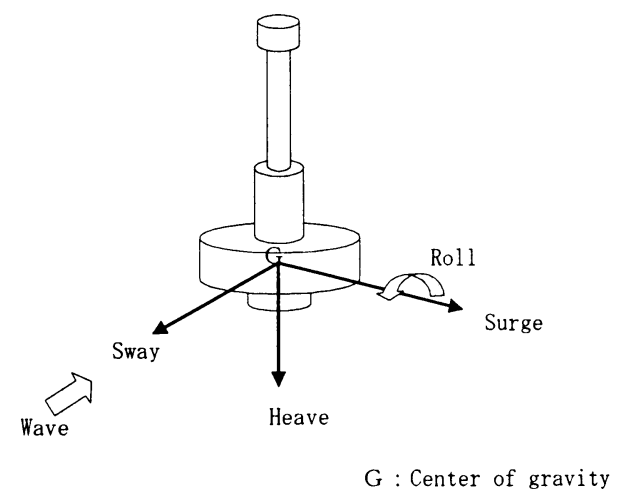

Fig.13 Definition of motion

\section{2 实験結果}

オペレーション状態, メンテナンス状態, 設置状態 (軽 荷状態）についての解析結果を Table 7〜9 に示す。解 析では計測データの極值を整理し, 有義値・最大値とし てまとめた。実験状況を Fig. 14 に示す。

Table 7 Results of experiment at operation condition

[Irregular wave]

\begin{tabular}{|c|c|c|c|c|c|c|c|c|}
\hline \multirow[b]{2}{*}{ Item } & \multirow[b]{2}{*}{ Unit } & \multirow{2}{*}{$\begin{array}{l}\text { Mean } \\
\text { value }\end{array}$} & \multicolumn{2}{|c|}{ Crest } & \multicolumn{2}{|c|}{ Trough } & \multicolumn{2}{|c|}{ Double amp. } \\
\hline & & & $\begin{array}{c}\text { Significant } \\
\text { values }\end{array}$ & $\begin{array}{c}\text { Max } \\
\text { values }\end{array}$ & $\begin{array}{c}\text { Significant } \\
\text { values }\end{array}$ & $\begin{array}{c}\text { Max } \\
\text { values }\end{array}$ & $\begin{array}{c}\text { Significant } \\
\text { values }\end{array}$ & $\begin{array}{l}\text { Mhax } \\
\text { values }\end{array}$ \\
\hline Sway & $\mathrm{m}$ & -24 & 4.9 & 8.9 & -4.9 & -9.0 & 8.9 & 17.7 \\
\hline Heave & $\mathrm{m}$ & 0.1 & 25 & 4.8 & -24 & -4.4 & 4.8 & 9.0 \\
\hline Roll & $\operatorname{deg}$ & -0.1 & 20 & 3.3 & -2.2 & -4.1 & 3.9 & 6.1 \\
\hline Lateral Aoc. & G & 0.000 & 0.113 & 0.190 & -0.113 & -0.201 & 0.215 & 0.391 \\
\hline Vertical Aoc. & G & -0.001 & 0.041 & 0.070 & -0.037 & -0.063 & 0.074 & 0.132 \\
\hline Moment 1 & $\tan \cdot m$ & -14 & 1,272 & 1,955 & $-1,325$ & $-2,407$ & 2483 & 3,873 \\
\hline Moment 2 & $\tan \cdot m$ & -48 & 1,010 & 1,475 & $-1,101$ & $-1,714$ & 2,063 & 3,008 \\
\hline Moment 3 & $\tan \cdot m$ & -29 & 1,454 & 1,957 & $-1,552$ & $-2,272$ & 2,886 & 4,014 \\
\hline Tension 1 & $\tan$ & 0.5 & 3.4 & 8.6 & -3.4 & -7.0 & 6.3 & 15.6 \\
\hline Tension 2 & ton & 0.1 & 3.0 & 5.7 & -3.0 & -6.0 & 5.7 & 10.9 \\
\hline
\end{tabular}

\begin{tabular}{|l|c|c|c|}
\hline \multicolumn{1}{|c|}{ [Regular wave } \\
\hline Sway & Unit & $\begin{array}{c}\text { Mean } \\
\text { value }\end{array}$ & Double amp. \\
\hline Heave & $\mathrm{m}$ & -1.7 & 3.4 \\
\hline Roll & $\mathrm{m}$ & 0.1 & 2.4 \\
\hline Lateral Acc & $\mathrm{G}$ & 0.002 & 0.086 \\
\hline Vertical Acc & $\mathrm{G}$ & 0.000 & 0.042 \\
\hline Moment 1 & ton $\cdot \mathrm{m}$ & -1 & 1,285 \\
\hline Moment 2 & ton $\cdot \mathrm{m}$ & -55 & 1,794 \\
\hline Moment 3 & ton $\cdot \mathrm{m}$ & -36 & 2,626 \\
\hline Tension 1 & ton & 0.4 & 3.2 \\
\hline Tension 2 & ton & 0.4 & 2.4 \\
\hline
\end{tabular}


Table 8 Results of experiment at maintenance condition

\begin{tabular}{|c|c|c|c|c|c|c|c|c|}
\hline \multirow[b]{2}{*}{ Item } & \multirow[b]{2}{*}{ Unit } & \multirow{2}{*}{$\begin{array}{l}\text { Mean } \\
\text { value }\end{array}$} & \multicolumn{2}{|c|}{ Chest } & \multicolumn{2}{|c|}{ Trough } & \multicolumn{2}{|c|}{ Double amp } \\
\hline & & & $\begin{array}{c}\text { Significat } \\
\text { values }\end{array}$ & $\begin{array}{c}\text { Max } \\
\text { values }\end{array}$ & $\begin{array}{c}\text { Significat } \\
\text { values }\end{array}$ & $\begin{array}{c}\text { Max } \\
\text { values }\end{array}$ & $\begin{array}{l}\text { Significart } \\
\text { values }\end{array}$ & $\begin{array}{c}\text { Max } \\
\text { values }\end{array}$ \\
\hline Suay & $\mathrm{m}$ & -3.6 & 1.2 & 4.1 & -1.5 & -4.4 & 22 & 4.9 \\
\hline Heave & $\mathrm{m}$ & 0.1 & 0.4 & 0.9 & -0.4 & -0.7 & 0.8 & 1.4 \\
\hline Roll & $\operatorname{deg}$ & 1.5 & 28 & 5.2 & -26 & -43 & 4.5 & 7.9 \\
\hline Lateral $\mathrm{AxC}$ & G & 0.003 & 0.074 & 0.129 & -0.074 & -0.148 & 0.146 & 0.252 \\
\hline Vertical Axc & G & 0.000 & 0.033 & 0.060 & -0.031 & -0.063 & 0.062 & 0.121 \\
\hline Mtmet 1 & $\tan \cdot m$ & -182 & 502 & 1,091 & -494 & $-1,005$ & 964 & 1,813 \\
\hline Memert 2 & $\tan \cdot m$ & -46 & 197 & 347 & -225 & -383 & 402 & 693 \\
\hline Momert 3 & $\tan m$ & -13 & 524 & 1,030 & -554 & $-1,147$ & 1,072 & 2,177 \\
\hline Tension 1 & $\tan$ & 0.9 & 1.9 & 3.5 & -20 & -3.9 & 3.7 & 6.1 \\
\hline Tension 2 & ton & -0.1 & 1.7 & 29 & -1.8 & -3.4 & 3.2 & 5.4 \\
\hline
\end{tabular}

Table 9 Results of experiment at light condition [Irregular wave]

(Mean wave period : $8 \mathrm{sec}$ )

\begin{tabular}{|c|c|c|c|c|c|c|c|c|}
\hline \multirow[b]{2}{*}{ Item } & \multirow[b]{2}{*}{ Unt } & \multirow{2}{*}{$\begin{array}{l}\text { Mean } \\
\text { value }\end{array}$} & \multicolumn{2}{|c|}{ Crest } & \multicolumn{2}{|c|}{ Trough } & \multicolumn{2}{|c|}{ Double anp. } \\
\hline & & & $\begin{array}{c}\text { Sigifican } \\
\text { values }\end{array}$ & $\begin{array}{l}\text { Mhis } \\
\text { values }\end{array}$ & $\begin{array}{c}\text { Significat } \\
\text { values }\end{array}$ & $\begin{array}{l}\text { Mar } \\
\text { values }\end{array}$ & $\begin{array}{c}\text { Sigifican } \\
\text { values }\end{array}$ & $\begin{array}{l}\text { Mak } \\
\text { values }\end{array}$ \\
\hline Suay & $\mathrm{m}$ & -0.9 & 0.7 & 1.5 & -0.6 & -1.5 & 1.1 & 24 \\
\hline Heave & $\mathrm{m}$ & -0.1 & 0.5 & 1.0 & -0.6 & -1.0 & 1.1 & 2.0 \\
\hline Roll & deg & -0.0 & 2.3 & 44 & -23 & 4.0 & 4.5 & 7.3 \\
\hline Lateral Aoc & G & 0.000 & 0.042 & 0.074 & -0.044 & -0.062 & 0.083 & 0.129 \\
\hline Vertical Aoc & G & -0.001 & 0.028 & 0.045 & -0.029 & -0.054 & 0.054 & 0.085 \\
\hline Tension I & $\tan$ & 0.5 & 24 & 4.1 & -24 & -3.7 & 4.6 & 7.7 \\
\hline Tension 2 & $\tan$ & 0.4 & 20 & 3.1 & -20 & -3.6 & 3.7 & 5.9 \\
\hline
\end{tabular}

[Irregular wave]

\begin{tabular}{|c|c|c|c|c|c|c|c|c|}
\hline \multicolumn{9}{|c|}{ [Irregular wave] } \\
\hline \multirow[b]{2}{*}{ Item } & \multirow[b]{2}{*}{ Unit } & \multirow{2}{*}{$\begin{array}{l}\text { Mean } \\
\text { value }\end{array}$} & \multicolumn{2}{|c|}{ Crest } & \multicolumn{2}{|c|}{ Trough } & \multicolumn{2}{|c|}{ Dable anp } \\
\hline & & & $\begin{array}{c}\text { Sigificant } \\
\text { values }\end{array}$ & $\begin{array}{c}\text { Mar } \\
\text { values }\end{array}$ & $\begin{array}{c}\text { Sigificart } \\
\text { values }\end{array}$ & $\begin{array}{l}\text { Mex } \\
\text { values }\end{array}$ & $\begin{array}{c}\text { Significar } \\
\text { values }\end{array}$ & $\begin{array}{c}\text { Mak } \\
\text { values }\end{array}$ \\
\hline Suay & $\mathrm{m}$ & -3.6 & 28 & 3.5 & -3.4 & -4.4 & 5.1 & 7.5 \\
\hline Heave & $\mathrm{m}$ & -0.1 & 0.5 & 0.9 & -0.5 & -0.8 & 1.0 & 16 \\
\hline Roll & deg & 0.9 & 3.1 & 5.2 & -3.1 & 4.9 & 5.9 & 8.6 \\
\hline Lateral AxC & G & -0.001 & 0.068 & 0.104 & -0.066 & -0.098 & 0.132 & 0.197 \\
\hline Vertical Aoc & G & -0.002 & 0.033 & 0.051 & -0.034 & -0.052 & 0.065 & 0.096 \\
\hline Tension 1 & $\tan$ & 0.7 & 3.4 & 5.4 & -3.4 & -5.7 & 6.7 & 10.3 \\
\hline Tension 2 & $\tan$ & 0.1 & 23 & 3.9 & -2.4 & -3.9 & 4.6 & 7.7 \\
\hline
\end{tabular}

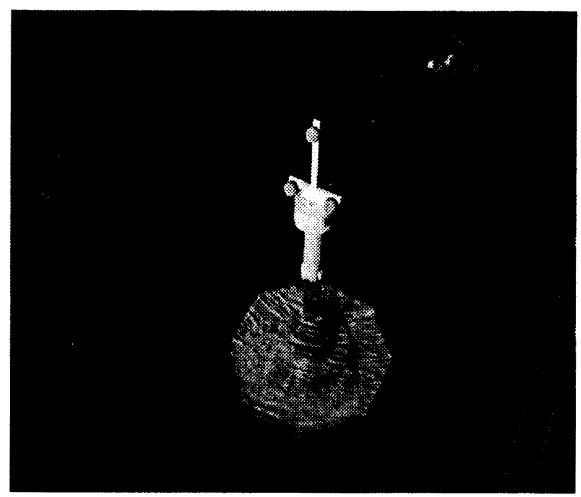

Fig.14 System model under measurement in irregular waves (operation condition)
実験結果によれば，オペレーション状態の設計波浪条 件である有義波高 $10 \mathrm{~m}$, 平均波周期 $14 \mathrm{sec}$ において左右 摇れは平均値 $-2.4 \mathrm{~m}$ を中心に最大 $\pm 9 \mathrm{~m}$, 横摇れは平均值 $0^{\circ}$ を中心に士 $4^{\circ}$ 程度, 曲げモーメントはライザー取り 付け部で最大 2400 ton $\cdot \mathrm{m}$ (応力複振幅 $22.3 \mathrm{~kg} / \mathrm{mm}^{2}$ ) , 係 留力は平均張力 (38ton) +9ton, -7 ton 程度となった。

また, メンテナンス状態では設計波浪条件の有義波高 $1.5 \mathrm{~m}$, 平均波周期 $6 \mathrm{sec}$ において左右摇れが平均值 $-3.6 \mathrm{~m}$ を中心に約 $\pm 4 \mathrm{~m}$ 程度, 横摇れは土5 $5^{\circ}$ 程度, 曲げモーメ ントはライザー中央よりやや下部 (M3) および躯体取り 付け部 (M1) で 1100ton 程度, 係留力は平均張力 42 ton士 4 ton 程度となった。さらにライザーが付いていない有義 波高 $1 \mathrm{~m}$, 平均波周期 $6 \mathrm{sec}$ 及び $8 \mathrm{sec}$ の設置状態において 左右摇れ土 $4 \mathrm{~m}$, 横摇れ $\pm 4^{\circ}$ 程度となることがあり動摇 がやや大きく作業時に注意を要すると思われる。

\section{3 計算結果との比较}

水槽試験の目的の一つは設計に使用している計算手 法を検証することである。本節では，水槽試験と同じ条 件にて実施した理論計算結果と水槽試験結果を比較し， 計算結果の推定精度を評価して手法の妥当性について 検討した。

本システムでは躯体に比べて係留系の規模が相対的 に大きく，躯体の動摇に及ぼす倸留系の動的挙動の影響 を無視できないと考えられたため, 係留系を 3 次元

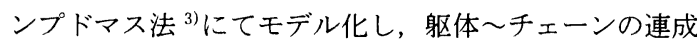
挙動として解析した。

不規則波中での躯体の動摇および係留力の最大值に ついて, 計算結果と実験結果を比較して Fig. 15，16 に

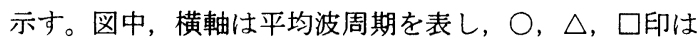
計算結果, ○, $\boldsymbol{\Delta}, \boldsymbol{\square}$ 印は試験結果を表している。左右 摇れ，横摇れで平均波周期 $14 \mathrm{sec}$ のときに計算結果の方 が運動が小さいのは，躯体とライザ一管を一体の剛体と みなし計算を行ったためと思われる。

躯体動摇およびチェーン軸力の計算值と実験值は比 較的よく対応しており，検討に使用する手法が妥当であ ると言える。

規則波中でのライザ一管の挙動について，水深方向の 変位分布を比較した結果を Fig. 17 に示す。また,この 時の曲げモーメントの振幅を Fig. 18, Table 10 に示す。 有限要素法 ${ }^{4)}$ による計算は, オペレーション状態, 波高 $5 \mathrm{~m}$ ，周期 $14 \mathrm{sec}$ の条件を対象に実施した。

また, 計算では水槽試験で計測した躯体の動摇を用い てライザー上端の変位を合成し，この変位を強制変位と して与えた。変位分布, 曲げモーメントともに計算結果 と実験結果はよく対応していると言える。 

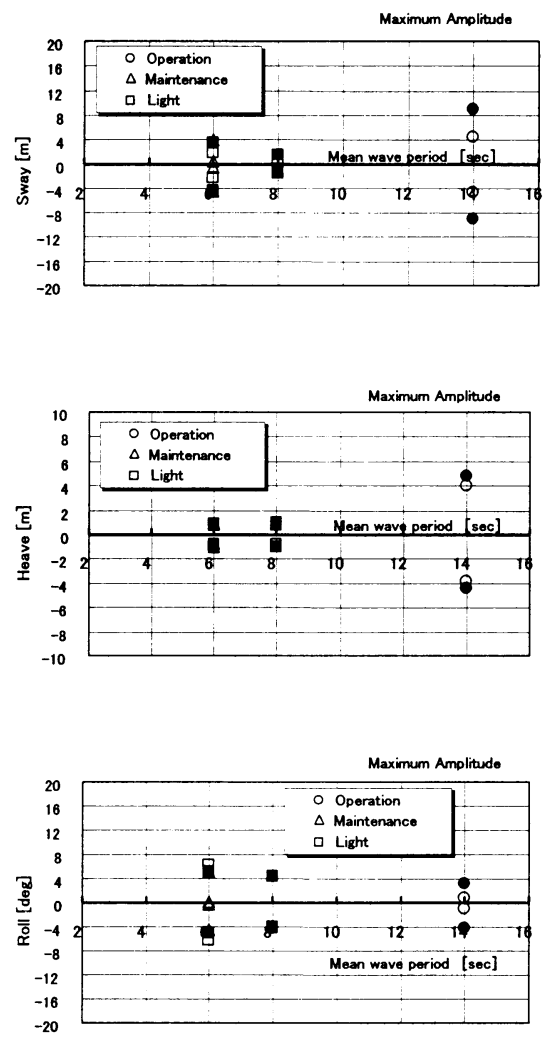

Fig.15 Comparison of calculated and measured responses in irregular waves

( maximum amplitude of motion)

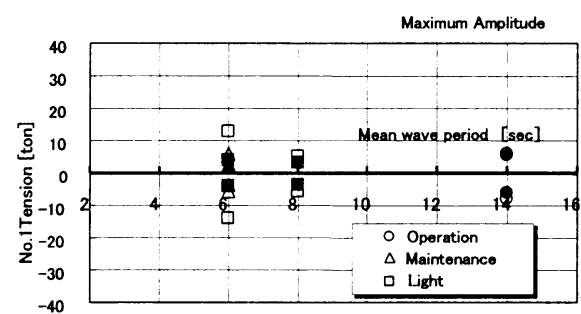

Fig.16 Comparison of calculated and measured responses in irregular waves

( maximum amplitude of No.1 tension)

以上, 設計に使用する係留躯体およびライザ一管の挙 動推定法の精度を評価するため, 水槽試験対応の計算を 実施し, 試験結果との比較により計算結果の妥当性につ いて検討した。この結果, 両者は比較的良く対応してい ることが分かった。したがって，本計算法を用いて倸留 系の基本設計を進めることとした。
Table 10 Amplitude of bending moment on the riser tube in regular waves

\begin{tabular}{|l|c|c|c|}
\hline & M1 & M2 & M3 \\
\hline Experiment & $643 \mathrm{ton} \cdot \mathrm{m}$ & $897 \mathrm{ton} \cdot \mathrm{m}$ & $1,313 \mathrm{ton} \cdot \mathrm{m}$ \\
\hline Calculation & $343 \mathrm{ton} \cdot \mathrm{m}$ & $857 \mathrm{ton} \cdot \mathrm{m}$ & $1,143 \mathrm{ton} \cdot \mathrm{m}$ \\
\hline
\end{tabular}
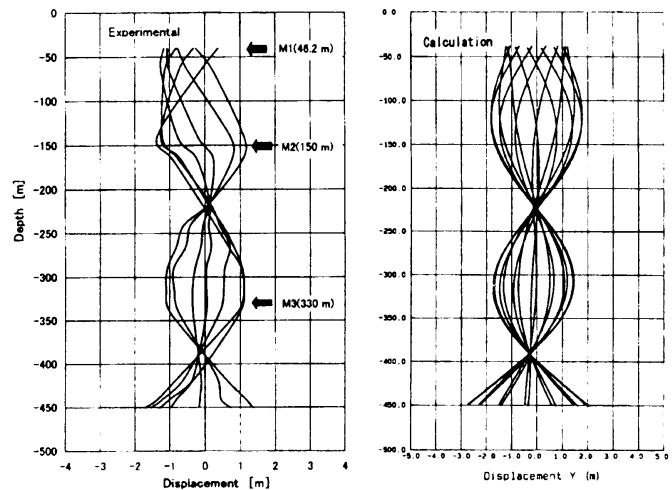

Fig.17 Calculated and measured distribution of horizontal displacement of riser tube

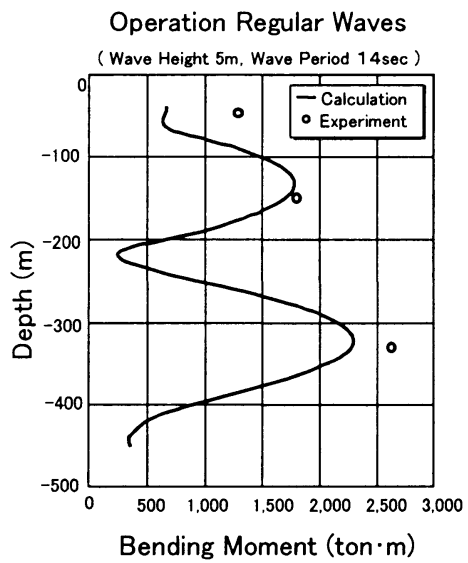

Fig.18 Comparison of calculated and measured response in regular waves( double amplitude of bending moment on the riser tube )

\section{5. 係留系の基本設計}

躯体システムの係留方式としてカテナリ一係留を選 定し, 理論計算および水槽試験による外乱下での動摇・ 係留性能の検討により本システムへの適用性に関する 
見通しを得た。本章ではこれらの検討結果を踏まえ， 設計外乱下での係留性能に及ぼすシンカー位置の影響 について理論計算により検討して係留系の基本要目を 決定した。

\section{1 㗨体システムの要目と設計外乱}

初期設計の段階では円断面の躯体形状にて検討が進 められていたが，搭載機器配置等の詳細検討により八角 形状案に設計変更されたため，基本設計ではこの形状を 対象とした。理論計算に使用した躯体の主要目を Table11 に示す。初期検討でも述べたように，外乱条件 が厳しいオペレーション状態を対象に諸検討を実施し た。

Table 11 Particulars of floating structure for the calculation

\begin{tabular}{|ll|c|}
\hline \multicolumn{2}{|c|}{ Conditon } & Operation \\
\hline Draft $\mathrm{d}$ & [m] & 40.0 \\
\hline Displacement $\Delta$ & [ton] & 5,784 \\
\hline
\end{tabular}

Table 12 Environmental conditions for the

\begin{tabular}{|c|c|ll|}
\hline \multicolumn{4}{|c|}{ calculation } \\
\hline Current & Wind & \multicolumn{1}{|c|}{ Irregular waves } \\
\hline $\begin{array}{cc}1.6 \mathrm{kn} \text { (surface) } \\
0 \quad \text { (sea bottom) }\end{array}$ & $50 \mathrm{~m} / \mathrm{sec}$ & $\begin{array}{l}\text { Significiant wave height } \\
\text { Mean wave period }\end{array}$ & $10 \mathrm{~m}$ \\
\hline
\end{tabular}

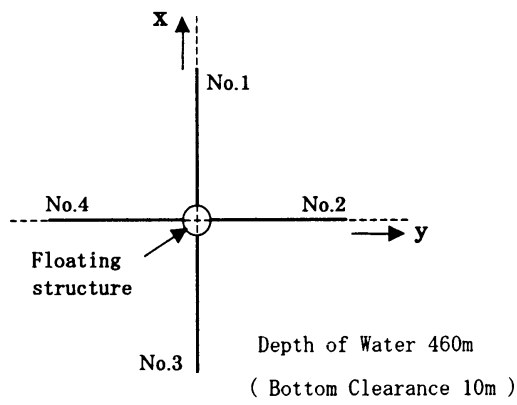

Fig.19 Arrangement of mooring chains

Fig 19 に示すようにコスト削堿を目的として本シス テムの倸留系は，4 本の係留チェーンにより構成した。 本システムの設置海域の水深は 460～550m であるが，釈 留系が最も緩く躯体の移動量が大きくなる水深 $460 \mathrm{~m}$ の場合について検討することとした。

係留系の検討に使用する外乱条件は, 設置海域での調 査結果に基づいて Table 12 のように設定した。

\section{2 保留性能の検討}

このような躯体の基本仕様に対して係留チェーンの 要目を決定するため, 以下に示すように, シンカー位置 の影響に関する検討を実施した。

初期検討にて示したようにコストやハンドリング・躯 体の排水量等を考慮して $56 \mathrm{~mm}$ 径のチェーン（ケース 3）を選定した。基本設計においても同じ要目のチェー ンを用い, シンカー位置を $1,000 \mathrm{~m} \sim 1,200 \mathrm{~m}$ の間で種々 変更して時刻歷シミュレーションにより躯体の応答と 係留力を求め, シンカー位置の影響について検討した。

外乱方向 $90^{\circ}$ ( チェーン No. 2 の方向より受ける状 態 ）における躯体の動摇および倸留チェーン張力の計 算結果を Fig. 20〜21 に示す。これらの結果より次のこ とが言える。

(1) Fig. 20 に示すように平均移動量（ Sway の平均 值 ）はシンカー位置が躯体に近づくにつれて大き くなる。平均傾斜（Roll の平均值）はシンカー 位置によらず, 約 0.6 で一定である。

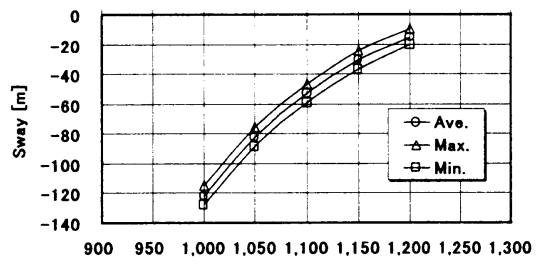

Sinker point $[\mathrm{m}]$
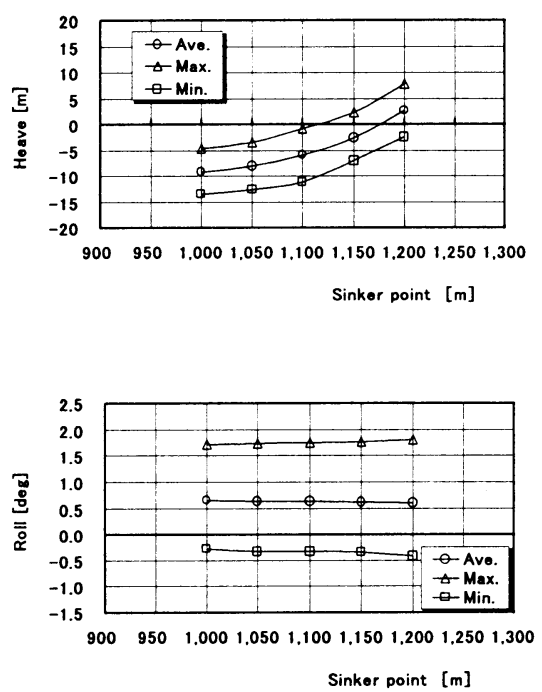

Fig.20 Motions of system under the designed external disturbance for the various sinker position 

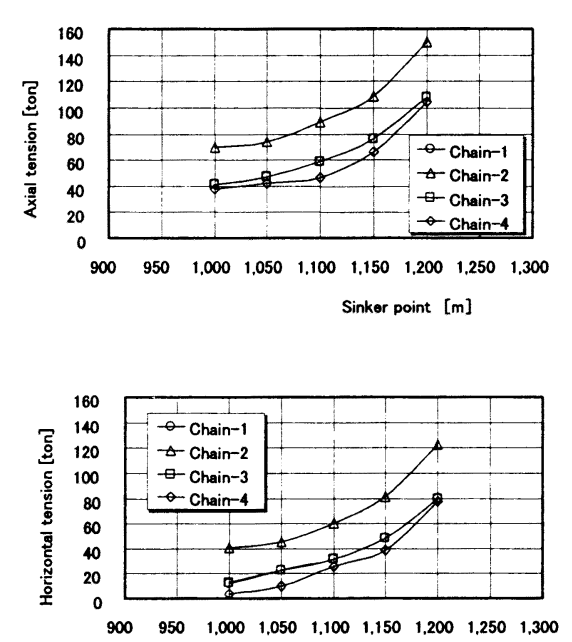

Sinker point $[\mathrm{m}]$

Fig.21 Chain tensions under the designed external disturbance for the various sinker position

(2) 波浪による変動成分はシンカー位置によらず同程 度の大きさである。

(3) Fig. 21 に示すチェーン張力の最大値はシンカー位 置が躯体に近づくにつれて小さくなり, シンカー位 置が近くなると張力変化率も小さくなる。

(4) 例えばシンカー位置が $1,150 \mathrm{~m}$ の場合, 設計外乱 下での平均横移動量は約 $30 \mathrm{~m}$, 最大張力は約 110 ton（静穏時の水平張力は約 30 ton）であり, Table 3 のケース 3 に示す第 3 種チェーン使用時の安全 率は約 2.3 となる。

\section{6. 結言}

本研究では哚層水を汲み上げ海洋を肥沃化させる係 留された躯体装置について動摇特性を実験的に把握評 価すると共に予測計算の一致度について検討を行った。 この結果次の結論を得た。

（1）躯体排水量約 5,800 トン,ライザー管長さ約 $400 \mathrm{~m}$ 哚層水汲み上げ装置の波浪中動摇実験の結果有 義波高 $10 \mathrm{~m}$, 平均波周期 $14 \mathrm{sec}$ という厳しい海象 条件において, 横摇れがほとんど無く良好な動摇 性能を有すること，4 本の係留索に作用する軸力 変動も 10 ton 程度に収まり装置の成立性が確認 できた。

（2）ライザーの弾性模型を用いたこの水槽試験にて 最大曲げモーメントが約 2,400 ton·m となり当初 計画したライザーの許容値を満足していること
が確認できた。

（3）動摇についての実験結果は倸留系をバネマス系 で表現した躯体・保留連成計算結果と良好に一致 し計算手法の妥当性が検証された。

（4）またライザー挙動についても有限要素法による 挙動解析結果は実験結果と十分な精度で一致し ており適用性が検証された。

（5）以上の結果により現在計画されている梁層水活 用型の海洋肥沃化装置について動摇・倸留の面か ら成立性が確認されると共に現有の計算手法の 妥当性が検証された。

\section{謝辞}

本研究は社団法人マリノフォーラム 21 の深層水活用 型漁場造成技術開発の一環として実施したものである。

本研究を進めるにあたり，終始貴重な助言を頂いた東 京大学教授高橋正征委員長をはじめ運営委員会各位, マ リノフォーラム 21 関倸者の方々, 並びにワーキンググ ループ各メンバーに対し染く感謝致します。

\section{考文献}

1）荻原誠功, 栗島裕治, 宮部宏彰, 大内一之：「哚層 水汲み上げ装置の概念設計」, 日本造船学会, 第 16 回海洋工学シンポジウム, 2001 年 7 月

2) Seiko Ogiwara, Yuji Awashima, Hiroaki Miyabe, Kazuyuki Ouchi : Conceptual Design of a Deep 0cean Water Upwelling Structure for Development of Fisheries, ISOPE OMS-2001, Sept. 2001

3) Yojiro Wada, Yoichi Yamaguchi : Analysis of Dynamic Response of a Moored Tanker and Mooring Lines in a Single Point Mooring System, 7th International Symposium on Practical Design of Ship and Mobile Units (PRADS '98), 1998

4）尾崎雅彦, 安川宏紀: 「水中線状構造の挙動推定法 とその応用」，三菱重工技報 Vol. 30, No. 11993 